\title{
ENVIRONMENTAL MANAGEMENT OF MINE WATER, CONSIDERING EUROPEAN WATER LEGISLATION. CASE STUDY OF MEGALOPOLIS MINES
}

\author{
Dimitrakopoulos D. ${ }^{1}$,Vassiliou E. ${ }^{2}$, Tsangaratos P. ${ }^{2}$, Ilia I. ${ }^{2}$ \\ ${ }^{1}$ Public Power Corporation (PPC-DMAOR/DEI),Kifisou \& Dirachiou 89,Athens, Greece \\ ddimitrakopoulos@gmail.com \\ ${ }^{2}$ National Technical University of Athens, School of Mining and Metallurgical Engineering, Laboratory of \\ Engineering Geology and Hydrogeology, \\ elvas@metal.ntua.gr,ptsag@metal.ntua.gr,gilia@metal.ntua.gr
}

\begin{abstract}
Mining activities causes many environmental problems to the surrounding areas, as other industrial activities do also. However mine water pollution, is considered a tough task to handle, as it requires specific regulations, quite distinct from those applicable to most other industrial processes. Even though there are several federal laws and regulations in Greece and in the European Union that influences the mining industry and mine water management, still certain factors complicates their implementation. The aim of this paper is to present a brief description of mining legislation in European Union and in Greece and also the efforts of Public Power Corporation (DEI), to integrate the Directive 2000/60/EC and Greek legislation in mining sector. The study is focused in Megalopolis open pit and in its surrounding, where lignite exploitation takes place and management of mine water is implemented. The outcomes of this effort are evaluated, considering the specific environmental conditions of the surrounding area and suggestions and methods, for mine water management, are proposed.
\end{abstract}

Key words: mine water, management, water legislation, open pit, Megalopolis, pollution.

\section{Introduction}

In mining industry, operations must meet standards that underlie federal and state laws which deal with the protection of the environment as a whole and especially surface and ground water from contamination. Until recently, mining in European Continent has been excluded from the scope of major environmental directives or has reserved a certain freedom for interpretation. Although the polluted ground and surface water has long been subject to legislative framework, mine water pollution has not been confronted equally.

Changes in European mining policy have been initiated as a result of the pressure from the public arena and its willingness to bring forward policy proposals involving environmental issues. A research project ERMITE (Environmental Regulation of Mine Waters in the European Union), was funded by the EU in order to provide guidelines for developing specific European legislation concerning water management in the mine sector. The general aim of the framework was to protect the water resources environment (rivers, lakes, coastal waters, and ground- 
water), preventing pollution and setting control mechanisms for all pollution sources, ensuring sustainable management of natural resources and methods of detergent techniques.

Mine Water, was adopted by ERMITE to be referred as water which is in mined ground (including waste rock/tailings depositories) and/or which is now flowing from mined ground into adjoining water bodies (such as streams, wetlands, lakes, aquifers and oceans). It defined the potential impacts of mining activity on water environment, at various phases of the mining cycle (ERMITE, 2004a). In many cases, mine water could create massive contaminating events due to high concentrations of specific chemical elements, and thus appropriate measures should be implemented.

Mining activity in Greece has a very long history, as it's revealed by many cases of systematic exploiting of natural resources in Ancient Greece. The silver mines of Lavrio and the famous marble of Naxos are examples, which helped the establishment of the various Greek city states. Nowadays, the most significant mining exploitation in Greece is exerted by Public Power Corporation (DEI), which produces about $60 * 10^{6}$ tn of lignite annually excavating $360 * 10^{6} \mathrm{~m}^{3}$ of waste material. At the present time, DEI (DEI) focuses the development of mining activity in Ptolemaida, Amynteo, Florina and Megalopolis. At the same time new lignite deposits have been discovered for exploitation in Drama and in Elassona. On average $1.7 \mathrm{~m}^{3}$ of water per tn of lignite is pumped for dewatering and protection of the mines from groundwater and surface water. In some mines, this ratio increases to $2.5 \mathrm{~m}^{3}$ water/tn of lignite.

The above mining activity is performed in accordance to national environmental legislation framework, which includes numerous modifications and replacements of previous rules, laws and instructions (Tsangaratos et al, 2008). This appears to be one of the drawbacks of development that extractive industry has to handle (Kavalopoulos, 2006). Moreover, as a Member State of EU, Greece must follow European Communities legislation, which takes precedence over national legal provisions. The European Community legislation includes treaties, as primary legislation, regulations, directives and decisions, as secondary legislation. The objectives of the Directives are to be achieved within a certain time-limit while leaving the national authorities the choice of form and means to be used (Hamor, 2004).

The aim of this paper is to present a brief description of the new perception which mine water management receives through European Union and the efforts of DEI to integrate the Directives 2000/60/EC, 2009/90/EC, 2008/105/EC and the Greek legislation considering mining activity. A case study of Megalopolis lignite mines is presented, were an actual mine water management program has been initiated under certain legislation framework.

\section{Mining legislation in European Union}

Mining activity was excluded from the Integrated Pollution Prevention and Control (IDEI) Directive (96/61/EC) and the Seveso II Directive (96/82/EC), yet introduced in the Environmental Impact Assessment Directive (97/11/EC). The Waste Framework Directive (75/442/EEC) stated that mining waste would be excluded where they are already covered by other legislation. In addition, the Water Framework Directive (WFD) (2000/60/EC) applies to mining activities in a generic sense but there is no specific water legislation addressing the requirements of this sector (Amezaga and Younger, 2004).

The current framework (Directive 2006/21/EC on the management of waste from extractive industries, in accordance with Directive 2000/60/EC) implies that certain measures should be 
Table 1. Main legislation framework in European Union concerning mining and water.

- Directive 2006/21/EC of the European Parliament and of the Council of 15 March 2006 on the management of waste from extractive industries and amending Directive 2004/35/EC - Statement by the European Parliament, the Council and the Commission.

- Directive 2003/105/EC of the European Parliament and of the Council of 16 December 2003 amending Council Directive 96/82/EC on the control of major-accident hazards involving dangerous substances.

- Council Directive 96/61/EC of 24 September 1996 concerning integrated pollution prevention and control.

- Directive 2000/60/EC of the European Parliament and of the Council of 23 October 2000 establishing a framework for Community action in the field of water policy.

- Directive 2004/35/CE of the European Parliament and of the Council of 21 April 2004 on environmental liability with regard to the prevention and remedying of environmental damage.

- Council Directive 75/442/EEC of 15 July 1975 on waste, in use for waste of extractive industry which are not included in Directive 2006/21/EC.

- Council Directive 92/32/EEC of 30 April 1992 amending for the seventh time Directive 67/548/EEC on the approximation of the laws, regulations and administrative provisions relating to the classification, packaging and labelling of dangerous substances.

- Council Directive 85/337/EEC of 27 June 1985 on the assessment of the effects of certain public and private projects on the environment.

- Directive 2001/42/EC of the European Parliament and of the Council of 27 June 2001 on the assessment of the effects of certain plans and programmes on the environment.

- Directive 2003/4/EC of the European Parliament and of the Council of 28 January 2003 on public access to environmental information and repealing Council Directive 90/313/EEC.

taken by the extractive industries in order to prevent soil and water contamination. In particular, these measures should present a waste management plan that would prevent or reduce the disposal of waste and the negative impact of them, encourage waste recovery through recycling, re-use or reclaiming and finally to encourage the short and long-term safe disposal of waste. Concerning water resources, they should evaluate the quantities and the quality of the pumped water, minimize surface and groundwater contamination, and finally treat the contaminated water before discharging. The main mining and water legislation framework in EU is shown in Table 1.

\section{Mining legislative framework and water policy in Greece}

Mining legislation in Greece, although it prevents irrational mining, is responsible for a weak environmental performance. There are numerous federal laws and regulations that influence Greek mining industry (Table 2). However, four laws, concerning environmental matters, are prominent for Greek mining industry, Code of Mining and Quarrying Works (CMQW), L. 998/1979, L. 1650/1980 and Interministerial Decree 69269/5387/1990. 
Table 2. Main Mining and water legislation in Greece.

- Law and Decree-law which adapt EU directives in the Greek legislation

- D.L. 51/2007 (FEK 54/A'/8.3 2007) Determination of measures and procedures for the holistic protection and management of water resources in accordance of Directive 2000/60/EC

- L 3199/2003 (FEK 280/A'/9.12.2003) Protection and management of water resources - according with the Directive 2000/60/EC

- Decisions regarding disposal limits of mine water which concern certain mining companies

- Decisions regarding disposal limits of liquid effluents applied in prefecture level

- Procedure for Environmental Permitting

- Joint Ministerial Decision (KYA) 126880/2007 (FEK 435/B'/29.3.2007)

- KYA 37111/2021/2003 (FEK 1391/B'/29.9.2003)

- KYA 13727/724/2003 (FEK 1087/B'/5.8.2003)

- KYA 11014/703/F104/2003 (FEK 332/B'/20.3.2003)

- KYA 25535/3281/2002 (FEK 1463/B'/20.11.2002)

- KYA 15393/2332/2002 (FEK 1022/B'/5.8.2002)

- Law 3010/2002 (FEK 91/A'/25.4.2002) reconciliation of 1650/1986 with 97/11/EC and $96 / 61 / \mathrm{EC}$

- KYA 69269/5387/1990 (FEK 678/B'/25.10.1990)

- Law 1650/1986 (FEK 160/A'/16.10.1986) On Protection of the Environment

Concerning environmental issues, the CMQW states that mining and quarrying works should be performed in a way that environmental damage, should be restricted to the minimum extent. It also defines that mining firms are obligated to implement mitigation measures for adverse impacts. For this purpose, mining enterprises have to co-operate with the governmental agencies as well as Prefecture and Local authorities, especially for the after-use planning of mine sites. The involvement of many authorities, agencies and institutions (Ministry of Environment, Physical Planning and Public Works, Ministry of Agriculture, Ministry of Development, Prefecture agencies, Greek Mines Inspectorate) that appear to be responsible for the environmental issues in Greece, could be accused in some extent for weak environmental protection performance. They lead to delays in the environmental permitting procedure, operational problems and declaration of mining works (Kaliampakos and Damigos 2000).

The main features of the current legal framework concerning mining activities in Greece are the following:

(a) Environmental protection is covered by general environmental rules, 
(b) Land-use rules govern whether land is available for mining activity,

(c) An environmental impact assessment study is always required in order to proceed to mine development,

(d) Reclamation of mined land is obligatory; however, the reclamation requirements are only qualitatively defined,

(e) Reclamation bonds (namely letter of credits) are being used in order to ensure that mining companies will perform the required reclamation works.

As already discussed although the concept of mine water management is newly introduced in the European legislation, Greece still does not have specific legislation for mine water. There is limited reference, in mine water considering it as industrial effluent, in order to prevent and minimize the potential pollution of the adjoining water bodies. Nevertheless, many efforts for the determination of the environmental terms in mines with specific obligations concerning the mining exploitations are done through the Joint Ministerial Decisions (KYA).

\section{Case Study of Megalopolis lignite mines}

In Megalopolis, three lignite open pit mines operate today, Xoremi, Marathousa and Kiparissia, whereas Thoknia lignite mine has recently finished its activity (1994). A power plant for the compulsion of lignite and generation of electricity is also located in this area. Four are the significant characteristics of the area (Fig.1):

- Alfios River flows near all the mines and several diversions of its riverbed were made, for the protection and proper operation of the mines.

- Waste and by-products of the desulfurization plant gradually fill the remnant void of Thoknia open pit mine, where a "lake" has been created also.

- A poor aquifer exists in the area of Thoknia, below the lignite layers in the neogene sediments.

- In the carbonate rocks, which form the basement and the surrounding mountains of the mines, a karstic system exists. Three karstic aquifers of great importance have been defined there.

Under the scope of mining exploitation in Megalopolis, DEI is obliged to obtain an exploitation license from the competent Ministry (YPEXODE). This license shall be accompanied by an order of adoption environmental terms, as described in the relevant KYA num. YPEXODE/GDP/DPS/rel.100532/200/23.1.2004. In this particular KYA, the obligations of DEI and measures taken for the management and protection of waters are as follows:

1. The pluvial water that is pumped from surface ponds in the mine undergoes relevant treatment before discharging in surface recipients.

2. All diversion works of surface waters to Alfios River are kept free from sediment and vegetation, in order to ensure discharge capacity of the river.

3. The groundwater pumped from the mines, is used to cover the industrial needs of DEI. In case there is quantitative adequacy and appropriate quality, it is available to cover water supply or irrigation needs of the region.

4. The total water balance in the immediate and wider range of intervention is determined with accuracy. The impacts on the hydrological balance of the region are investigated, giving emphasis on the river system of the region. The above are included in a hydro- 


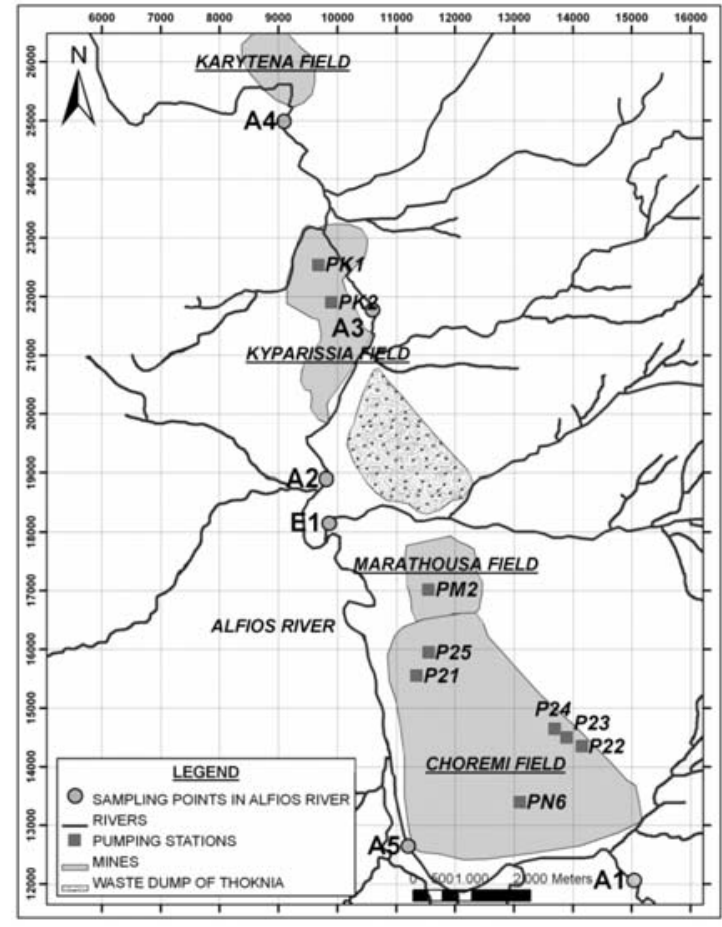

Fig. 1: Map of sampling points in Megalopolis mines.

geological report, which is submitted to the authorities.

5. The quality of water discharged in Alfios River is monitored and $\mathrm{pH}$, temperature and conductivity are measured on continuous basis. Measurements of the concentrations of pendulous and dissolved particles, as well as trace elements $\mathrm{As}, \mathrm{Cd}, \mathrm{Pb}, \mathrm{Zn}, \mathrm{Cr}, \mathrm{Hg}, \mathrm{Ni}$, $\mathrm{V}$ and $\mathrm{Cu}$, are done once per three months, according to the specific KYA. Moreover, the liquid wastes of the mining activity undergo biological treatment for the purpose of reuse.

6 . The water level and pumping rate of ground water is recorded on continuous basis.

\section{Evaluating the mine water management}

The management of mine water during and after the exploitation is of great importance for the mining companies and the local societies (Dimitrakopoulos D., 1996, Modis K., 2009). DEI is obliged to carry out several chemical analyses and to present them in annual reports.

In Megalopolis mine, the measurements described above were plotted in diagrams, and statistical analysis was done in order to evaluate them (Fig.2, 3, 4).

$\mathrm{PH}$ and electrical conductivity (EC) are within the acceptable limits, in accordance with the environmental terms (EC 2000 $\mathrm{SS} / \mathrm{cm}$ and $\mathrm{pH}$ 7.5-8.5). The total dissolved solids (TDS) appeared with particularly high values, in samples taken from the sumps (Fig. 2). The particular high values of Molybdenum (upper limit 75ppb) observed in A2, A3, and A4 of Alfios River are attributed to the chemical composition of lignite (Fig. 3). The concentrations of sulphide $\mathrm{SO}_{4}{ }^{-2}$ are found to be within the acceptable potable limits, with an exception of the A3 during 2004, which, however, seems to decrease, reaching in 2006 the acceptable limits (Dimitrakopoulos et al., 2007). 

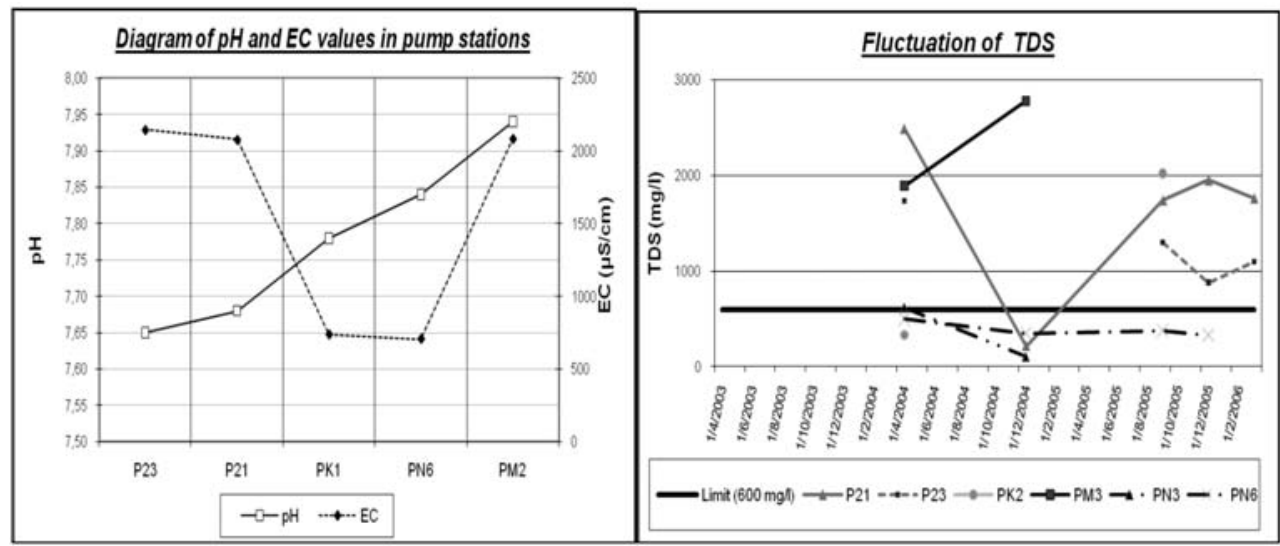

Fig. 2: Diagrams of average values of $\mathrm{pH}$ and $\mathrm{EC}$ in Megalopolis and the fluctuation of TDS for the period 2003-2006.

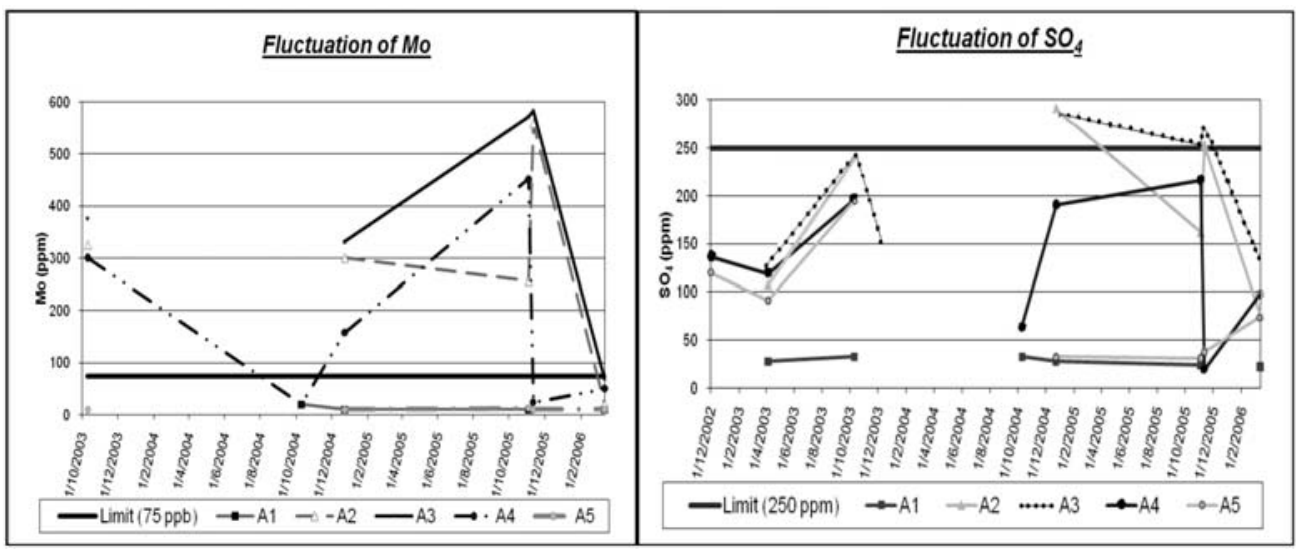

Fig. 3: Diagrams of Mo values and $\mathrm{SO}_{4}^{-2}$ in Alfios River.

In Figure 4, the statistical analysis is presented, in which the results are interesting. The maximum average value in $\mathrm{pH}$ was measured in Alfios River but this value isn't above the limits for potable use. The high $\mathrm{pH}$ value (alkaline environment) does not help the dissolution of cations from the geological formations or the waste dump. As a consequence the water of Alfios River is generally of good quality. The lower mean values, of parameters under investigation, are observed in the karstic aquifer. This is a strong indication that it has not been affected by mining activity and generally is of good quality. The water of the ponds and the ground water in the waste dump area of Thoknia, are the most degrading and present the higher values in E.C., TDS, $\mathrm{SO}_{4}{ }^{-2}, \mathrm{Mo}$ (fig. 4). These high values are not reflected in the samples from the deep aquifer below the dump, the karstic aquifer or Alfios River. The conclusion from this analysis is that the mining activities have not affected the main water resources of the area. The increased concentrations of Mo in Alfios are due to the fact that it is part of the geochemical texture of lignite in Megalopolis and it is highly soluble. All the others chemical elements which are increased, come from the urban and agricultural activities in the area. Main part for the increased values of $\mathrm{Ca}^{2+}$ and $\mathrm{Mg}^{2+}$ has the geological formations (carbonic) in Megalopolis (Waterchem, 2007). 


\begin{tabular}{|c|c|c|c|c|c|c|c|c|c|c|}
\hline & Sam ple ID & $\mathrm{pH}$ & $E C \_s / c m$ & TDS $\mathbf{m g} / 1$ & \begin{tabular}{|l|l} 
Ca ppm & ,
\end{tabular} & Mg ppm & so, ppm & Mn ppb & Ba ppb & Mo ppb \\
\hline \multirow{3}{*}{ AVVERS } & MIN & 7,64 & 250,00 & 180,00 & 6,40 & 4,65 & 19,50 & 2,00 & 24,00 & 2,08 \\
\hline & MAX & 8,42 & 1300,00 & 1010,00 & 229,00 & 25,10 & 573,00 & 64,00 & 70,30 & 583,00 \\
\hline & AVERAGE & 8,04 & 638,04 & 415,87 & 94,04 & 14,43 & 134,67 & 11,90 & 46,87 & 242,74 \\
\hline \multirow{3}{*}{$\begin{array}{l}\text { PONDS I-II } \\
\text { IN THOKNAA }\end{array}$} & MIN & 6,90 & 840,00 & 570,00 & 118,00 & 10,90 & 308,00 & 2,00 & 50,80 & 730,00 \\
\hline & MAX & 8,00 & 4370,00 & 3120,00 & 684,00 & 64,30 & 1807,00 & $2154, \infty$ & 113,00 & 11110,00 \\
\hline & AVERAGE & 7,58 & 2113,85 & 1733,85 & 350,77 & 34,31 & 1050,77 & 434,42 & 86,25 & 4487,3 \\
\hline \multirow{3}{*}{$\begin{array}{c}\text { PONDS IN } \\
\text { OTHER MINES }\end{array}$} & MIN & 6,85 & 430,00 & 102,00 & 5,80 & 1,49 & 82,00 & 2,00 & 18,00 & 5,00 \\
\hline & MAX & 11,00 & 3660,00 & 2810,00 & 580,00 & 129,00 & 1650,00 & 2090,00 & 205,00 & 547,00 \\
\hline & AVERAGE & 7,77 & 1815,72 & 1273,90 & 299,71 & 52,59 & 728,00 & 472,50 & 80,90 & 104,96 \\
\hline \multirow{3}{*}{ KARSTIC AQUFERS } & MIN & 7,65 & 380,00 & 230,00 & 75,00 & 8,39 & 16,10 & 2,20 & 20,00 & 10,00 \\
\hline & $\operatorname{MAX}$ & 8,10 & 550,00 & 330,00 & 87,80 & 17,00 & 37,30 & $112, \infty 0$ & 65,30 & 12,60 \\
\hline & AVERAGE & 7,99 & 487,00 & 293,33 & 81,88 & 14,45 & 29,58 & 46,90 & 34,40 & 10,98 \\
\hline \multirow{3}{*}{$\begin{array}{c}\text { DEEP AQUFERIN } \\
\text { THOKNA }\end{array}$} & MIN & 7,20 & 570,00 & 360,00 & 34,80 & 12,10 & 4,90 & 4,10 & 52,40 & 5,00 \\
\hline & MAX & 8,10 & 1130,00 & 730,00 & 210,00 & 20,00 & 228,00 & 538,00 & 503,00 & 32,50 \\
\hline & AVERAGE & 7,63 & 882,00 & 582,00 & 148,68 & 15,97 & 97,86 & 158,07 & 209,12 & 18,78 \\
\hline \multirow{3}{*}{$\begin{array}{l}\text { GROUNDWATER } \\
\text { ARROUND WASTE } \\
\text { DUMP }\end{array}$} & MIN & 6,60 & 540,00 & 450,00 & 11,80 & 11,60 & 0,39 & 59,00 & 0,12 & 5,00 \\
\hline & MAX & 8,90 & 2940,00 & 1710,00 & 506,00 & 91,70 & 1181,00 & 5082,00 & 884,00 & 97,70 \\
\hline & AVERAGE & 7,65 & 1504,11 & 950,77 & 186,71 & 29,44 & 180,94 & 687,04 & 242,73 & 31,64 \\
\hline \multirow{3}{*}{$\begin{array}{l}\text { GROUNDWATERIN } \\
\text { WASTE DUMP }\end{array}$} & MIN & 6,41 & 870,00 & 580,00 & 115,00 & 0,30 & 86,70 & 14,00 & 4,00 & 5,00 \\
\hline & MAX & 9,40 & 4980,00 & 3200,00 & 1030,00 & 167,00 & 2080,00 & 4792,00 & $250,0 \mathrm{~d}$ & 5800,00 \\
\hline & AVERAGE & 7,46 & 2587,91 & $1959,8 \phi$ & 459,94 & 73,22 & 1224,23 & 772,5 & 39,94 & 616,94 \\
\hline
\end{tabular}

Fig. 4: Statistical analysis of sampling in Megalopolis (Waterchem 2007).

Besides the obligations of DEI and the measures described above, the company participated in three European Research Programs (Minwater, Interwatpol, Waterchem). In these the impact of mining activity in the aquatic environment was investigated and various methods, for the management and the protection of surface and groundwater, were proposed (Dimitrakopoulos D., 1998, Stefouli M., 2005). During these Research Projects, the geochemical modeling PhreeqC was applied in Megalopolis in order to investigate the quality of mixed waters from the karstic aquifer, Alfios River and the mine water from Thoknia area (Vassiliou et al., 2008). The result of the investigation verified that there is no remarkable influence of the dumping area to the quality of Alfios River and karstic aquifer.

\section{Conclusions}

- In Megalopolis lignite mines, a coordinated attempt to monitor and control the quality of groundwater and surface waters, with regularly water table measurements and samplings, is made, beyond the obligatory measurements suggested by the relevant KYA.

- According to the relevant KYA, DEI has planned scheduled water table measurements in order to control the water balance of the area

- In the area of Megalopolis there is intensive mining activity. However the water quality of Alfios River and karstic aquifer, which are the main water bodies of the area, is generally good. This is attributed to the implementation of the process, which follows the relative legislation framework.

- The legislation framework concerning the management of water in Greece appears to 
have certain gaps, since there is not specific legislation for treatment and management of mine water. The lawmaking of the relevant KYA, applied to each Prefecture does not solve the problem.

\section{References}

Amezaga, J., Younger L., 2004. ERMITE: supporting European policy making on mine wastes and waters. In Proceedings of Mine Water 2004., Newcastle upon Tyne, UK. University of Newcastle upon Tyne, 19-23 September, Vol 2, 41- 46.

Dimitrakopoulos, D., Vassiliou, E., Founda, M., 2007. Impacts of mining activities on water resources to Megalopolis lignite area, EGU General Assembly, Vienna., Austria, 15-20 April. ,

Dimitrakopoulos D, Voight, R., 1996 "Postmining water management problems in Ptolemais-Amynteon Lignite district, Macedonia, Greece". Proceedings of the Geocongress, Grundwasser und Rohstoffgewinnung, Freiberg, Germany, pp 49-54.

Dimitrakopoulos, D., Koumantakis, J., Poutios, G., Heliadis, K., 1998: Methods of artificial recharge in areas with open pit exploitations. Case of South field Open Pit, West Macedonia, Greece. 5th International SWEMP, Ankara, Turkey.

ERMITE Consortium, 2004. "Mining Impacts on the Fresh Water Environment: Technical and Managerial Guidelines for Catchment-Focused Remediation”. In: Younger PL, Wolkersdorfer C (eds). Mine Water and the Environment, Suppl. Issue 1. Berlin: Springer.

Hamor, T., 2004. Sustainable Mining in the European Union: The Legislative Aspect. Environmental Management, 33, 252-261.

Kaliampakos, D., Damigos, D., 2000. Mining Regulation in Greece: Perspectives on its Environmental Performance, Proceedings V International Conference on Clean Technologies for the Mining Industry, Santiago, Chile, 9-13 May, 271-277.

Modis, K., Vatalis, K., Papantonopoulos, G., Sachanidis, Ch. 2009 Uncertainty management of a hydrogeological data set in a greek lignite basin, using BME Published online: 13/1/2009 in Stochastic Environmental Research and Risk Assessment DOI 10.1007/s00477-008-0298-3 Publisher Springer-Verlag Berlin / Heidelberg.

Kavalopoulos, C., 2006. "Extractive activity in Greece: importance, opportunities, challenges, problems", 3rd European Workshop: Mining and Environment, Patra, Greece, 1-3 June.

Stefouli, M., Dimitrakopoulos, D., Papadimitrakis, J. Charou, E., 2005: Monitoring and assessing internal waters (lakes) using operational space born data, field measurements and numerical models. EWRA European water 9/10/2005, pp.25-33, E.W. Publications.

Tsangaratos, P., Vassiliou, E., Grigorakou, E., Rozos, D., 2008. Environmental management of Mine Water in Greece and in the European Union, International Conference Geology and Water Management: Resources, Risks and Regulations, Athens.

Vassiliou, E., Founda, M., Dimitrakopoulos, D., 2008. The water quality of Alfios River and the effects on it from the mining activities, in the area of Megalopolis. Estimating the quality of the river system by Phreeqc modeling, EGU General Assembly, Vienna, Austria, 13 -18 April.

WATERCHEM: Optimization of Mine Water Discharge by Monitoring and Modelling of Geochemical Processes and Development of Measures to Protect Aquifers and Active Mining Areas from Mine Water Contamination. Financed by RFCS, Research Fund For Coal and Steel. Contract: No RFC-CR-03006 (10/2003-2/2007), 3rd, 4th, 5th, 6th, final technical reports by DEI, Project leader D. Dimitrakopoulos. 